\title{
The effect of pyrolysis temperature and feedstock on date palm waste derived biochar to remove single and multi-metals in aqueous solutions
}

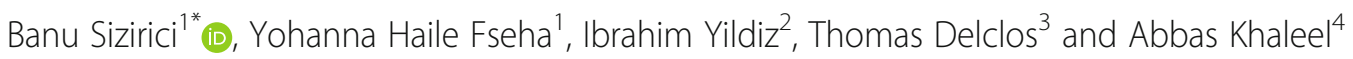

\begin{abstract}
In this study, leaf and frond date palm waste as feedstock was used to derive biochars. The effects of pyrolysis temperatures on their physical and chemical properties, and their capacity to remove copper, iron, nickel and zinc from single and multi-metal solutions at various $\mathrm{pH}$ values were investigated. Analytical and spectroscopic techniques such as scanning electron microscopy, energy dispersive X-ray, Fourier transform infrared spectroscopy, $X$-ray diffraction, carbon, hydrogen, nitrogen, sulfur elemental analysis, Brunauer Emmett Teller analysis were conducted for characterization. The pore volume, surface area, $\mathrm{pH}$, and total carbon content of date palm leaf and frond biochar increased while functional groups and hydrogen, nitrogen and oxygen content of biochar decreased with increasing pyrolysis temperature compared to feedstock. The removal efficiencies and sorption capacity for single and mixed metal ions were found between 98 and close to $100 \%$ and 2.4 and $3.0 \mathrm{mg} \mathrm{g}^{-1}$ by leaf and frond biochar samples at $\mathrm{pH}>6$, respectively. Biochar obtained from different feedstock at different pyrolysis temperature did not show any statistically significant improvements on the removal of single or mixed metals from aqueous solutions. The date palm leaf or frond biochar obtained at low pyrolysis temperature is as effective to remove metals as the ones obtained at high pyrolysis temperatures. Therefore, to consume less energy to produce biochar at lower temperature which exhibits same effective removal efficiency will be a win-win solution in terms of sustainability and economy. As a result, date palm waste biochar can be effectively used to remove metals in water and wastewater.
\end{abstract}

Keywords: Biochar, Charcoal, Date palm, Frond, Leaf, Mixed metals

\section{Introduction}

Metals in the environment originate from a wide variety of anthropogenic sources such as battery manufacturing, power plants, fertilizers, pesticides, mining, wastewater, smelting, and sewage sludge. Metals do not biodegrade and are highly toxic due to their bioavailability [1]. When heavy metals discharged into the environment, they have a tendency to bio-accumulate and result in

\footnotetext{
* Correspondence: banu.yildiz@ku.ac.ae

${ }^{1}$ Civil Infrastructure and Environmental Engineering Department, Khalifa University Science and Technology, Abu Dhabi, United Arab Emirates
} Full list of author information is available at the end of the article cancer, pancreatic damage, and stomach and intestinal distress to humans [2]. They can be phytotoxic, and limit agricultural applications such as use of wastewater sludge in fields [3]. Therefore, there is an emerging need to treat the metal contaminated wastewater with appropriate technologies. Several conventional methods are already in use such as membrane filtration, chemical precipitation, ion exchange and electrodialysis to treat heavy metal loaded waters. However, some of these methods are often not economical due to energy requirement; some of them produce toxic by-products and sludge, and in some cases may result in membrane

(c) The Author(s). 2021 Open Access This article is licensed under a Creative Commons Attribution 4.0 International License, which permits use, sharing, adaptation, distribution and reproduction in any medium or format, as long as you give

appropriate credit to the original author(s) and the source, provide a link to the Creative Commons licence, and indicate if changes were made. The images or other third party material in this article are included in the article's Creative Commons licence, unless indicated otherwise in a credit line to the material. If material is not included in the article's Creative Commons licence and your intended use is not permitted by statutory regulation or exceeds the permitted use, you will need to obtain permission directly from the copyright holder. To view a copy of this licence, visit http://creativecommons.org/licenses/by/4.0/ 
fouling. According to Amin et al. [4], they also tend to be ineffective in the treatment of wastewaters with high heavy metal concentrations. Adsorption, on the other hand, is simple and easy technique to operate for treatment purposes. Nevertheless, the use of commercial adsorbents for treatment systems is limited due to ensuing high cost. Therefore, development of novel adsorbent materials that are efficient, cheap, easy to grow and harvest, and abundant in nature is crucial [5]. Recently, biochar has gained popularity as a bioadsorbent material for the removal of a variety of pollutants from contaminated waters because of its low cost, wide availability, and desirable physical and chemical surface features as adsorbent [6].

Biochar is a black carbonaceous product of biomass such as wood, plant, or sludge when heated at temperatures greater than $250{ }^{\circ} \mathrm{C}$ in the absence of air or in limited air [7]. Biochar is considered alkaline; it is composed of mainly carbon and small amounts of minerals and volatile organics and is resistant to biodegradation [8]. It consists of $40-75 \%$ carbon, and it is not easily broken down by microorganisms [9]. Moreover, biochar is porous, and it has a large surface area and a variety of functional groups on the surface [10].

Altering pyrolysis condition affects the composition of the biochar [11]. Slow pyrolysis is often associated with the formation of higher contents of nitrogen, sulfur, calcium, magnesium and phosphorus in addition to greater surface areas and enhanced cation exchange capacities. This is due to the fact that easily decomposable and volatile components of biochar such as oxygen, hydrogen, nitrogen, total phosphorus and sulfur are lost during the slow pyrolysis [7]. Chemical changes are introduced to biochar during the pyrolysis at various temperatures. As the biomass gets dehydrated, aliphatic bonds are converted into aromatic bonds which are consolidated into stable graphene structures [12].

Sun et al. [13] have shown that the pyrolysis temperature and the type of feedstock are influential factors on the production rate, thermal stability, carbon content and elemental composition of biochar. In a similar fashion, at higher pyrolysis temperatures, the surface area and porosity increase along with the concentration of minerals including potassium, phosphorus, calcium and magnesium on the surface of the adsorbent which in turn would allow ion exchange with metals and result in higher adsorption capacities [14]. Also, as the pyrolysis temperature increases, some physical and chemical changes occur in biochar such as a decrease in cell pore diameter and an increase in the specific surface area [7].

Functional groups on the surface of adsorbents are responsible for the sorption of adsorbates [15]. According to $\mathrm{Li}$ et al. [16], the functional groups responsible for sorption include carboxyl, hydroxyl and amino groups, and the concentration of these groups often decreases with an increase in the pyrolysis temperature as compared to the feedstock.

Studies have demonstrated that biochars derived from a variety of sources such as paper mill waste, corn, willow, hazelnut, pine, oak, and manure have potential to remove a number of contaminants in wastewaters such as dyes, pharmaceuticals, anions, pesticides and heavy metals [7]. Table 1 reports studies that used biochar originating from a variety of sources to remove metals [12, 16-31]. From the Table 1, according to Chen et al. [17], hardwood and corn stalk biochar showed $95 \%$ of copper and $90 \%$ of zinc removals. Alkali activated hydrothermal carbonization (HTC) biochar, removed almost $100 \%$ of copper [18]. Pellera et al. [19] studied compost, rice husks, olive pomace and orange waste biochar to remove copper and found that compost biochar had the highest removal (94\%) followed by rice husks (90\%), orange waste $(89 \%)$ and olive pomace $(78 \%)$.

Utilizing waste materials to produce biochar is a sustainable solution in terms of cost effectiveness and impact on global warming potential (GWP). Alhashimi and Aktas [32] compared the cost of biochar and activated carbon and they found that granular activated carbon and powdered activated carbon cost 6.4 and $\$ 1.2-2 \mathrm{~kg}^{-1}$ respectively as compared to coconut shell biochar, pinewood biochar and forestry debris biochar which cost $0.8, \quad 0.9$ and $\$ 1.5 \mathrm{~kg}^{-1}$ respectively. In terms of environmental impact, Alhashimi and Aktas [32] deduced that biochar had a negative impact on GWP with a value of $-0.9 \mathrm{~kg}$ $\mathrm{CO}_{2}$-eq kg $\mathrm{kg}^{-1}$ as compared to activated carbon $(6.6 \mathrm{~kg}$ $\mathrm{CO}_{2}$-eq $\left.\mathrm{kg}^{-1}\right)$. Similarly, according to Roberts et al. [33], the net greenhouse gas emissions for biochar from stover and yard waste were also negative, at 864 and $-885 \mathrm{~kg} \mathrm{CO}_{2}$-eq emissions reductions per ton of dry feedstock. This is due to the ability of biochar to remove carbon as compared to activated carbon. The energy requirements for biochar were lower requiring only $6.1 \mathrm{MJ} \mathrm{kg}^{-1}$, whereas, activated carbon required $97 \mathrm{MJ} \mathrm{kg}^{-1}$ [32].

Therefore, utilizing date palm waste as a low-cost adsorbent will be a sustainable waste utilization solution, since the date palm waste is abundant in the Gulf Cooperation Council Countries. In fact, annually, $50 \mathrm{kt}$ of wastes are generated from date palm trees which end up in landfills in the United Arab Emirates [34]. Similarly, wastes from 22 million date palms are disposed directly in the landfills or burns in open fields in the Kingdom of Saudi Arabia [35]. Accordingly, the objective of this study is to bring attention to utilize date palm leaf and palm frond as biochar/biomass feedstock at different pyrolysis temperature to remove single and mixed metals in wastewater. Date palm leaf and palm frond as 
Table 1 Comparison of removal efficiencies [adsorption capacity] of various biochars

\begin{tabular}{|c|c|c|c|c|}
\hline Study & Adsorbents & Adsorbates & Removal efficiency [adsorption capacity] & Reference \\
\hline 1 & $\begin{array}{l}\text { Buck wheat, corn cobs, } \\
\text { mulberry wood, poultry manure and } \\
\text { peanut shells BC pyrolyzed at } 350 \text {, } \\
450,550 \text { and } 650^{\circ} \mathrm{C}\end{array}$ & $\begin{array}{l}\text { (1) Lead } \\
\text { (2) Cadmium } \\
\text { (3) Arsenic }\end{array}$ & $\begin{array}{l}\text { (1) } 97.5 \%\left[2.5 \mathrm{mg} \mathrm{g}^{-1}\right] \\
\text { (2) }<90 \%\left[1.5 \mathrm{mg} \mathrm{g}^{-1}\right] \\
\text { (3) } 42 \%\left[0.5 \mathrm{mg} \mathrm{g}^{-1}\right]\end{array}$ & {$[12]$} \\
\hline \multirow[t]{3}{*}{2} & Rape straw BC-NaOH & Cadmium & $90 \%\left[72 \mathrm{mg} \mathrm{g}^{-1}\right]$ & {$[16]$} \\
\hline & Rape straw $\mathrm{BC}-\mathrm{MnO}_{x}$ & & $95 \%\left[81 \mathrm{mg} \mathrm{g}^{-1}\right]$ & \\
\hline & Rape straw $\mathrm{BC}-\mathrm{FeO}_{x}$ & & $47 \%\left[67 \mathrm{mg} \mathrm{g}^{-1}\right]$ & \\
\hline \multirow[t]{2}{*}{3} & Hard wood and corn stalk BC & Copper & $95 \%$ & {$[17]$} \\
\hline & & Zinc & $90 \%$ & \\
\hline \multirow[t]{2}{*}{4} & Activated HTC BC & $\begin{array}{l}\text { (1) Copper } \\
\text { (2) Cadmium }\end{array}$ & $\begin{array}{l}\text { (1) } 100 \%\left[31 \mathrm{mg} \mathrm{g}^{-1}\right] \\
\text { (2) } 100 \%\left[34 \mathrm{mg} \mathrm{g}^{-1}\right]\end{array}$ & [18] \\
\hline & HTC BC & & $\begin{array}{l}\text { (1) } 16 \%\left[4.0 \mathrm{mg} \mathrm{g}^{-1}\right] \\
\text { (2) } 5.6 \%\left[1.5 \mathrm{mg} \mathrm{g}^{-1}\right]\end{array}$ & \\
\hline \multirow[t]{4}{*}{5} & Compost BC & & $93.6 \%\left[3.6 \mathrm{mg} \mathrm{g}^{-1}\right]$ & [19] \\
\hline & Rice husks BC & Copper & $90.1 \%\left[2.5 \mathrm{mg} \mathrm{g}^{-1}\right]$ & \\
\hline & Olive pomace BC & & $77.8 \%\left[2.2 \mathrm{mg} \mathrm{g}^{-1}\right]$ & \\
\hline & Orange waste $\mathrm{BC}$ & & $88.7 \%\left[3.3 \mathrm{mg} \mathrm{g}^{-1}\right]$ & \\
\hline \multirow[t]{3}{*}{6} & Non-impregnated rice husk BC & Arsenic & $25 \%$ & {$[20]$} \\
\hline & Ca impregnated rice husk $B C$ & Arsenic & $95 \%$ & \\
\hline & $\mathrm{Fe}^{0}$ impregnated rice husk $\mathrm{BC}$ & Arsenic & $58 \%$ & \\
\hline 7 & Soybean stalk BC & Mercury & $86.4 \%\left[0.7 \mathrm{mg} \mathrm{g}^{-1}\right]$ & {$[21]$} \\
\hline \multirow[t]{3}{*}{8} & Oak bark BC & Arsenic & $70 \%\left[7.4 \mathrm{mg} \mathrm{g}^{-1}\right]$ & [22] \\
\hline & & Cadmium & $50 \%\left[5.4 \mathrm{mg} \mathrm{g}^{-1}\right]$ & \\
\hline & & Lead & Nearly $100 \%\left[13.1 \mathrm{mg} \mathrm{g}^{-1}\right]$ & \\
\hline 9 & Sugar beet tailings $B C$ & Chromium (VI) & $98 \%\left[123 \mathrm{mg} \mathrm{g}^{-1}\right]$ & [23] \\
\hline 10 & $\begin{array}{l}\text { Pinewood }(P) B C \\
\text { Rice husk (R) BC }\end{array}$ & Lead & $\begin{array}{l}\text { P: Nearly } 80 \%\left[4.1 \mathrm{mg} \mathrm{g}^{-1}\right] \\
\text { R: Nearly } 60 \%\left[2.4 \mathrm{mg} \mathrm{g}^{-1}\right]\end{array}$ & [24] \\
\hline \multirow[t]{3}{*}{11} & Chitosan modified bamboo BC & Lead & $50 \%\left[25.1 \mathrm{mg} \mathrm{g}^{-1}\right]$ & [25] \\
\hline & & Cadmium & $45 \%\left[14.3 \mathrm{mg} \mathrm{g}^{-1}\right]$ & \\
\hline & & Copper & Close to $55 \%$ & \\
\hline \multirow[t]{3}{*}{12} & Olive mill solid waste BC & Lead & $>80 \%$ & {$[26]$} \\
\hline & & Copper & $>80 \%$ & \\
\hline & & Selenium & $<20 \%$ & \\
\hline \multirow[t]{3}{*}{13} & Groundnut shell BC & Cadmium & $99.93 \%\left[0.14 \mathrm{mg} \mathrm{g}^{-1}\right]$ & {$[27]$} \\
\hline & & Mercury & $99.99 \%\left[0.14 \mathrm{mg} \mathrm{g}^{-1}\right]$ & \\
\hline & & Lead & $100 \%\left[0.18 \mathrm{mg} \mathrm{g}^{-1}\right]$ & \\
\hline 14 & Groundnut shell BC & Cadmium & $99.20 \%\left[29.0 \mathrm{mg} \mathrm{g}^{-1}\right]$ & [28] \\
\hline 15 & Corn straw BC & Cadmium & $99.24 \%\left[38.9 \mathrm{mg} \mathrm{g}^{-1}\right]$ & {$[29]$} \\
\hline 16 & Dairy manure derived $B C$ & Lead & $92.8-99.8 \%$ & {$[30]$} \\
\hline 17 & $\begin{array}{l}\text { Carbon microspheres derived from } \\
\text { walnut shell }\end{array}$ & $\begin{array}{l}\text { Chromium } \\
\text { Lead } \\
\text { Cadmium } \\
\text { Copper }\end{array}$ & $\begin{array}{l}{\left[792 \mathrm{mg} \mathrm{g}^{-1}\right]} \\
{\left[638 \mathrm{mg} \mathrm{g}^{-1}\right]} \\
{\left[574 \mathrm{mg} \mathrm{g}^{-1}\right]} \\
{\left[345 \mathrm{mg} \mathrm{g}^{-1}\right]}\end{array}$ & {$[31]$} \\
\hline
\end{tabular}

biochar were not utilized widely in wastewater treatment applications. In addition, the available biochar studies mostly deal with single solute removal. There are a few studies dealing with mixed ion solutes removal. As a matter of fact, multiple ions are present in wastewater; therefore, it is vital to study removal of single as well as 
multi-ion solutes in wastewater [36]. Moreover, studies dealing with different feedstock and pyrolysis effect on biochar to remove mixed metals using statistical analysis are needed. In this study, physical and chemical features of date palm leaf/frond biochar obtained at different pyrolysis temperatures $\left(400,500\right.$ and $600^{\circ} \mathrm{C}$ ) were characterized, and the effects of feedstock and pyrolysis temperatures on the removal efficiencies of heavy metals such as copper, zinc, nickel and iron in mixed metal and single metal solutions at different $\mathrm{pH}$ values were investigated statistically. The result of this study may help and enable end-users to apply date palm-derived biochar as a low-cost adsorbent in their treatment systems.

\section{Materials and methods}

\section{Preparation of biochar and stock solutions}

The biochar was composed of date palm waste, namely fronds and leaves. The fronds and leaves were dried under the sun. The fronds were chopped to 1 $\mathrm{cm}$ and the leaves were chopped to $0.5 \mathrm{~cm}$ length. The moisture and volatility contents were determined according to The American Society for Testing and Materials D1762-84 (Standard Test Method for Chemical Analysis of Wood Charcoal). The date palm fronds/leaves were placed in a stainless-steel container and packed tightly to ensure no room for air, and covered with aluminum foil. The container was placed in an electrical muffle furnace (Vulcan 3-550) and pyrolyzed as shown in Fig. 1 at 400, 500 and $600{ }^{\circ} \mathrm{C}$ at a rate of $8{ }^{\circ} \mathrm{C} \mathrm{min}^{-1}$ temperature increment. After completion of pyrolysis, the biochar samples were left to cool for 3 to $4 \mathrm{~h}$ inside the furnace. The date palm leaf and frond biochar samples were labeled as Frond 400 (frond was pyrolyzed at $400{ }^{\circ} \mathrm{C}$ ), Frond 500 (pyrolyzed at $500^{\circ} \mathrm{C}$ ), Frond 600 (pyrolyzed at $600^{\circ} \mathrm{C}$ ), Leaf 400 (leaf was pyrolyzed at $400^{\circ} \mathrm{C}$ ), Leaf 500 (pyrolyzed at $500{ }^{\circ} \mathrm{C}$ ) and Leaf 600 (pyrolyzed at $600{ }^{\circ} \mathrm{C}$ ). Later, the date palm frond and leaf biochar samples were ground and sieved to obtain a particle size of about $0.15 \mathrm{~mm}$. The sieved biochar samples were washed with distilled water and dried at $105^{\circ} \mathrm{C}$ for 2 $\mathrm{h}$ and placed inside air-tight containers in desiccators. Stock solutions of copper, nickel, zinc and iron of 5 $\mathrm{mg} \mathrm{L}^{-1}$ were prepared using copper sulfate pentahydrate, nickel chloride hexahydrate, zinc chloride and iron sulfate heptahydrate for the single solute and mixed metal solutes. All chemicals were of analytical grade and provided by Sigma Aldrich and Merck. The $\mathrm{pH}$ of the solutions was adjusted using $0.1 \mathrm{M} \mathrm{HCl}$ and $0.1 \mathrm{M} \mathrm{NaOH}$.

\section{Characterization of the adsorbent}

The characterization of the date palm frond and leaf biochar samples at different pyrolysis temperatures $(400$,

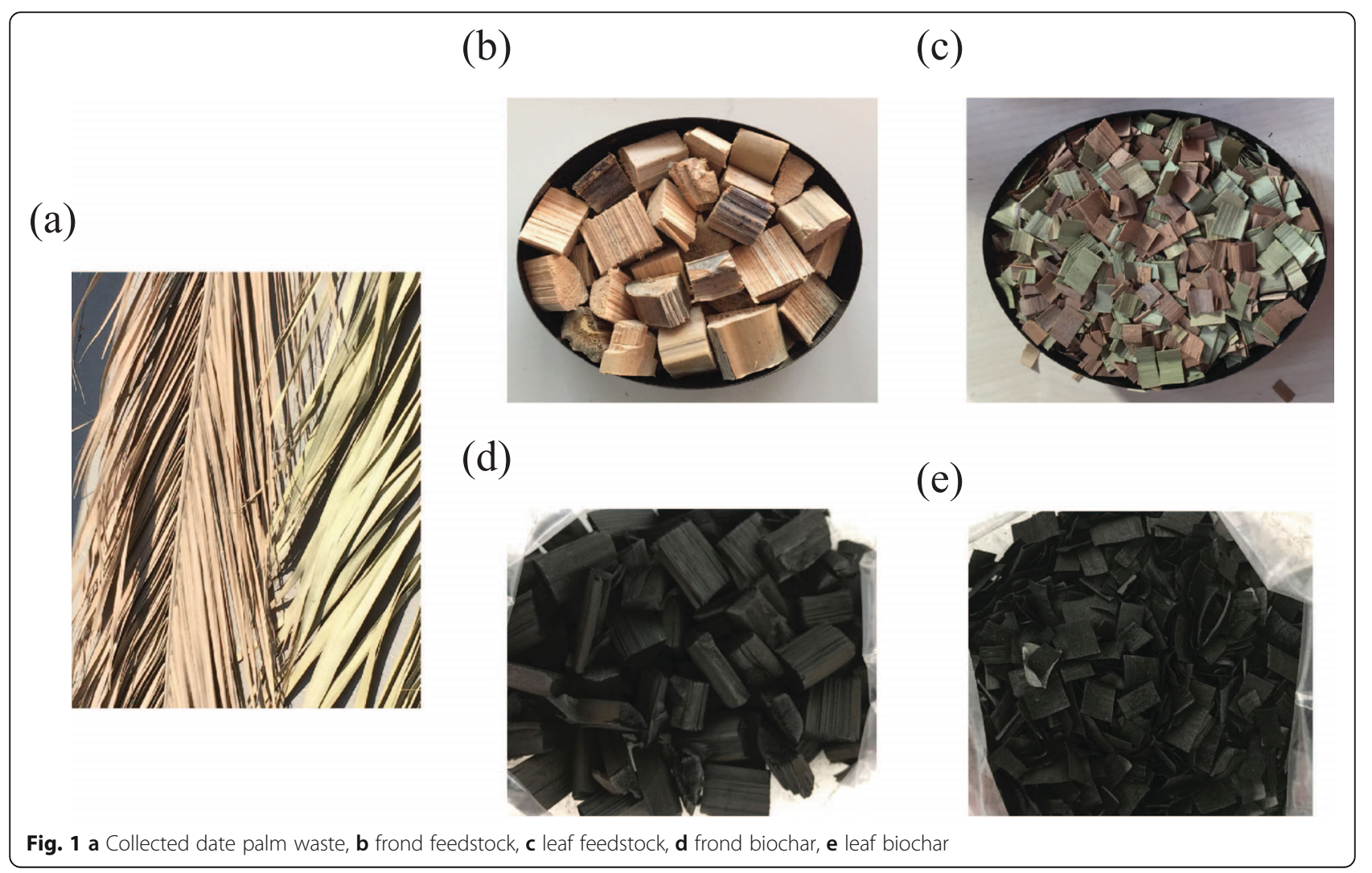


500 and $600{ }^{\circ} \mathrm{C}$ ) was performed using a variety of analytical techniques. Scanning electron microscopy (SEM) with a JEOL JSM-7610F was used to determine the morphology of the adsorbent. An accelerating voltage between 10 and $12 \mathrm{kV}$ with low probe current and a working distance of $8-15 \mathrm{~mm}$ was maintained during the analysis. Energy dispersive X-Ray (EDX) was used to obtain the elemental analysis of the biochar surface. XRay diffraction (XRD) spectroscopy with a D2 Phaser Bruker diffractometer with $\mathrm{CuK \alpha}$ radiation of wavelength $0.154 \mathrm{~nm}$ was conducted to obtain the mineral composition of the samples. Fourier transform infrared spectroscopy (FT-IR) with a Bruker Vertex 80v was used to identify the different functional groups present in the samples represented by their vibrational modes. Surface area was analyzed using nitrogen adsorption at $77 \mathrm{~K}$ with a Quantachrome Autosob-1. The Brunauer-EmmettTeller (BET) method was used to calculate the specific surface area. The Carbon, Hydrogen, Nitrogen, Sulfur (CHNS) content was analyzed using an elemental analyzer with a EuroEA Elemental Analyzer in which the samples were combusted at $980^{\circ} \mathrm{C}$, and the resultant gaseous species separated quickly allowing the detection of thermal conductivity. The $\mathrm{pH}$ of biochar samples was measured with a $\mathrm{pH}$ meter, HANNA instruments 2210, using biochar/water ratio of $1 / 10$ (v:v).

\section{Removal studies}

The effect of pyrolysis temperature and the effect of using either date palm frond or leaf derived biochar samples on the removal efficiencies of metal ions from the single and multi-metal solutions were studied in batch studies. In the experiments, $0.1 \mathrm{~g}$ of date palm frond or leaf biochar samples (namely, Frond 400, Frond 500, Frond 600, Leaf 400, Leaf 500 and Leaf 600) were added to solutions of $50 \mathrm{~mL}$ of $5 \mathrm{mg} \mathrm{L}^{-1}$ of iron, nickel, copper and zinc of single or mixed metal solutions. 0.1 $\mathrm{M}$ of $\mathrm{NaOH}$ and $0.1 \mathrm{M}$ of $\mathrm{HCl}$ were used to adjust the $\mathrm{pH}$ of the solutions at 2, 4, 6, 7, 8 and 10 using a $\mathrm{pH}$ meter. $50 \mathrm{~mL}$ of solutions were shaken at $200 \mathrm{rpm}$ for $20 \mathrm{~h}$ using a shaker, Bench Mark OrbiShaker. All samples were filtered using $0.45 \mu \mathrm{m}$ Whatman filter paper. The filtrates were analyzed to determine the concentrations of the metals in solutions using an inductively coupled plasma mass spectrometer (ICP-MS), NexION $350 \mathrm{X}$ dual channel. Removal efficiency was calculated as follows:

$$
\text { \%removal }=\frac{\mathrm{C}_{0}-\mathrm{C}_{\mathrm{e}}}{\mathrm{C}_{0}} * 100
$$

where, $\quad C_{0}=$ initial concentration, $\quad C_{e}=$ final concentration
To calculate the metal sorption capacity qe $\left(\mathrm{mg} \mathrm{g}^{-1}\right)$ of the biochar, the following formula was used:

$$
\mathrm{qe}=\left(\mathrm{C}_{0}-\mathrm{C}_{\mathrm{e}}\right) * \frac{\mathrm{V}}{\mathrm{m}}
$$

where, $\mathrm{V}$ is the sample volume and $\mathrm{m}$ the weight of the adsorbent.

\section{Data analysis}

Student's t-test, two-tailed with a 95\% confidence inter$\mathrm{val}$, and one-way analysis of variance (ANOVA) tests with $95 \%$ confidence interval were used to determine whether the increase of the pyrolysis temperature for the preparations of date palm frond or leaf derived biochar samples showed any significance on the metal ion removal efficiencies. T-test analysis was also used to investigate if different feedstocks namely date palm frond or leaf at different pyrolysis temperatures made any significance on the removal efficiencies of the metals.

\section{Results and discussion \\ Characterization of the samples}

The moisture contents of the date palm frond and leaf as feedstock were found to be 2.5 and $1.8 \%$ for date palm frond and leaf feedstock respectively. The volatile matter content was determined to be 47.7 and $39.6 \%$ for date palm frond and leaf feedstock respectively. The $\mathrm{pH}$ of the biochar samples was measured 9.2, 9.3 and 9.9 for Frond 400, 500 and 600 respectively; 8.4, 9.1 and 9.5 for Leaf 400, 500 and 600 respectively. Date palm frond and leaf derived biochar samples were in alkaline ranges which align with the other studies [37].

SEM results were used to determine the morphology of the date palm leaf and frond biochar as well as the feedstock. As Fig. 2 shows, the quantity and sizes of pores increased on the surface of biochar samples as the pyrolysis temperatures were increased. Frond 400, 500 and 600 had pore sizes with a value of 7.6-9.3, 13.918.6 and $24.6-26.4 \mu \mathrm{m}$ respectively. Leaf 400,500 and 600 had pore sizes with a value of $4.2-5.3,7.9-14.2$ and 22.9-25.3 $\mu \mathrm{m}$. Leaf 600 and Frond 600 had the largest quantity and size of pores as shown in Fig. 2. This in turn can result in larger pores for the adsorption process [35]. In date palm frond feedstock, the surfaces were curly indicating the presence of cellulose, hemicelluloses and lignin. Furthermore, the leaf and frond feedstocks had an integrated structure without considerable pores as compared to the pyrolyzed biochar [38].

EDX analysis showed that both for leaf 400-600 and frond 400-600 samples, calcium content increased with an increase in the pyrolysis temperature as shown in Table 2. This is ascribed to the presence of insoluble calcium carbonate, and calcium concentration decreases only at temperatures of $700{ }^{\circ} \mathrm{C}$ and higher due to the 


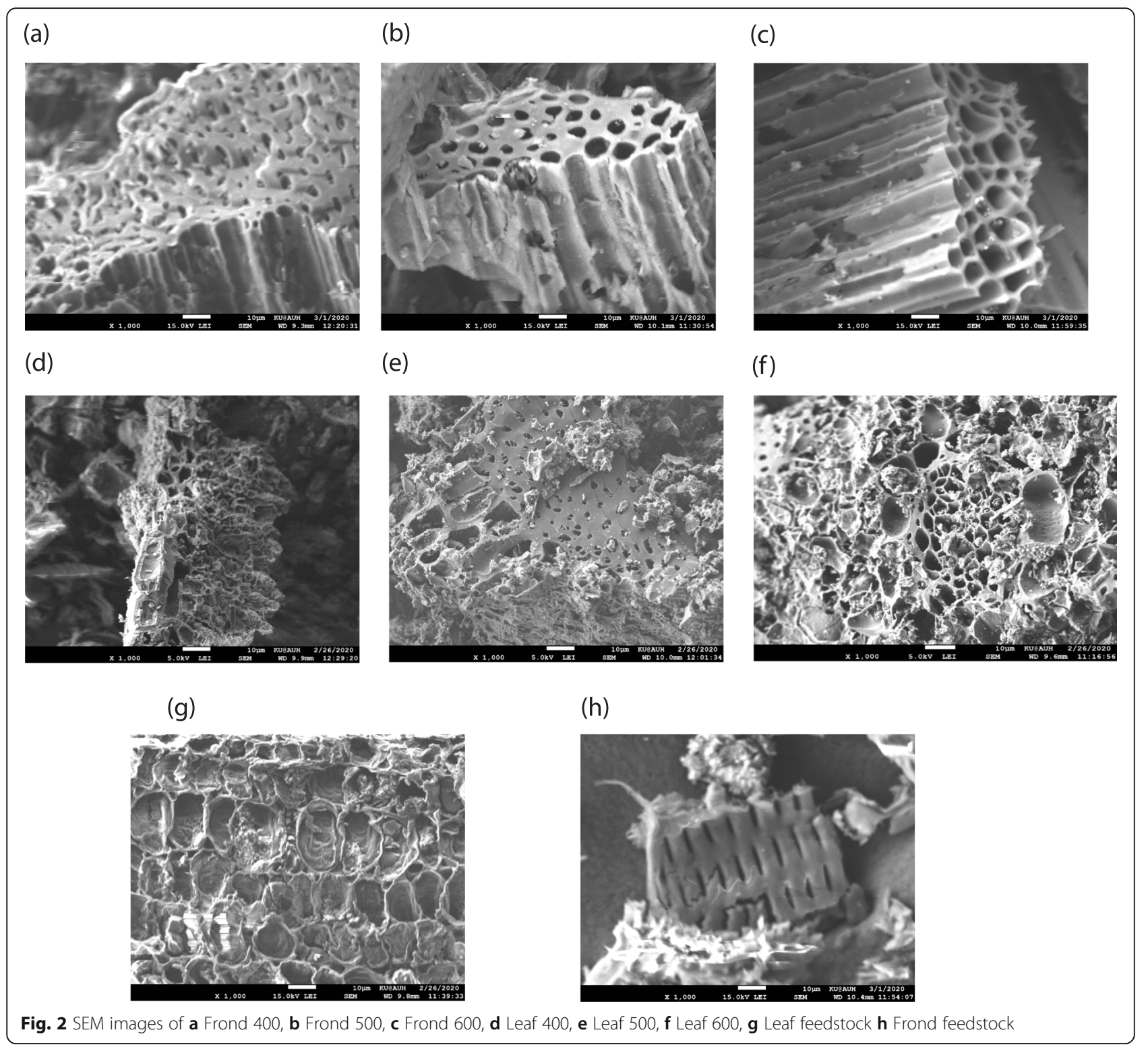

Table 2 Elemental analysis for leaf and frond feedstock and biochar samples

\begin{tabular}{|c|c|c|c|c|c|c|c|c|c|c|c|c|c|c|c|c|}
\hline \multirow[b]{2}{*}{ Sample } & \multicolumn{11}{|c|}{ EDX analysis } & \multicolumn{5}{|c|}{ CHNS analysis } \\
\hline & $\% \mathrm{C}$ & $\% 0$ & $\% \mathrm{Mg}$ & $\% \mathrm{Si}$ & $\% \mathrm{~S}$ & $\% \mathrm{Cl}$ & $\% \mathrm{Ca}$ & $\% \mathrm{P}$ & $\% \mathrm{Na}$ & $\% \mathrm{P}$ & $\% A \mathrm{I}$ & $\% \mathrm{~N}$ & $\% \mathrm{C}$ & $\% \mathrm{H}$ & $\% \mathrm{~S}$ & $\% 0$ \\
\hline Leaf feedstock & 37.7 & 57.9 & 0.5 & 1.5 & 0.7 & 0.4 & 1.0 & 0 & 0 & 0 & 0.3 & 0.6 & 31.2 & 4.5 & 0 & 63.7 \\
\hline Leaf 400 & 44.7 & 39.7 & 0.4 & 10.3 & 0.4 & 0.4 & 3.9 & 0.3 & 0 & 0 & 0 & 0.6 & 47.8 & 3.0 & 0 & 48.6 \\
\hline Leaf 500 & 49.1 & 35.7 & 0.3 & 9.9 & 0 & 0.5 & 3.8 & 0.3 & 0.4 & 0 & 0 & 0.6 & 49.2 & 2.1 & 0 & 48.1 \\
\hline Leaf 600 & 67.3 & 25.0 & 0.5 & 3.4 & 0 & 0.0 & 3.9 & 0 & 0 & 0 & 0 & 0.6 & 57.7 & 1.0 & 0 & 29.1 \\
\hline Frond feedstock & 45.5 & 47.6 & 0 & 0 & 0 & 2.4 & 4.6 & 0 & 0 & 0 & 0 & 0.2 & 41.9 & 5.8 & 0 & 52.1 \\
\hline Frond 400 & 66.9 & 23.3 & 0.8 & 1.5 & 0.8 & 1.0 & 4.6 & 0.7 & 0.5 & 0 & 0 & 0.1 & 46.9 & 3.5 & 0 & 49.8 \\
\hline Frond 500 & 72.0 & 17.8 & 0.9 & 1.6 & 0.6 & 1.3 & 4.2 & 1.0 & 0.7 & 0 & 0 & 0.1 & 50.9 & 3.0 & 0 & 45.6 \\
\hline Frond 600 & 74.8 & 11.5 & 0.4 & 0.4 & 1.0 & 4.3 & 5.0 & 1.0 & 1.6 & 0 & 0 & 0.1 & 66.7 & 2.3 & 0 & 30.9 \\
\hline
\end{tabular}


calcination of calcium carbonate to soluble calcium oxide [35]. For Frond 400 and 500 samples, magnesium content increased with an increase in the pyrolysis temperature. This is mainly due to the presence of insoluble periclase, magnesium oxide [7,35]. The presence of the other elements such as silicon and aluminum can be attributed to metallic oxides present in the biochar samples [39]. Both CHNS and EDX analyses shown in Table 2 showed that as the pyrolysis temperature increased, the carbon content of leaf and frond biochar samples increased compared to feedstock due to the carbonization and the thermochemical decomposition of the biomass in which cellulose, hemicellulose and lignin break down, and new resistant graphitic bonds form [39]. Carbon content of leaf feedstock was $31 \%$ and increased to $47-$ $57 \%$ in leaf biochar samples. Similarly, the carbon content of frond feedstock was $42 \%$ and increased to $47-67 \%$ for frond biochar samples. It was observed that oxygen content decreased in the leaf and frond biochar samples compared to leaf and frond feedstock with an increase in the pyrolysis temperature due to the volatilization [7]. Oxygen content of leaf feedstock was $64 \%$ and decreased to $29-49 \%$ for leaf biochar samples. The oxygen content of frond feedstock was $52 \%$ and decreased to $30-50 \%$ for leaf biochar samples. Comparably, hydrogen content decreased in leaf and frond biochar samples compared to leaf and frond feedstock with an increase in the pyrolysis temperature. The hydrogen content of leaf feedstock was $4.5 \%$ and decreased to 1.0 $3.0 \%$ for leaf biochar samples. The hydrogen content of frond feedstock was $5.8 \%$ and decreased to $2.3-3.5 \%$ for frond biochar samples. Nitrogen content relatively unchanged between leaf/frond feedstock and leaf/frond biochar samples, which is consistent with the findings of other studies $[13,40]$.

Figures 3a, b show the FT-IR spectra of leaf and frond feedstock and frond and leaf biochar pyrolyzed at 400, 500 and $600{ }^{\circ} \mathrm{C}$. The band at $1620 \mathrm{~cm}^{-1}$ represented alkenyl $\mathrm{C}=\mathrm{C}$ stretching vibrations. It can also represent $\mathrm{H}-\mathrm{O}-\mathrm{H}$ bending band of water which tends to decrease with an increase in pyrolysis temperature. The band at $1701 \mathrm{~cm}^{-1}$ represented $\mathrm{C}=\mathrm{O}$ from $-\mathrm{COOH}$, amides, esters and ketones [39]. The band at $1724 \mathrm{~cm}^{-1}$ represented esters and aldehydes. The furthest bands at 1764 and $1811 \mathrm{~cm}^{-1}$ represented alkyl carbonate and aryl carbonate respectively [41]. It can be noticed that the alkyl carbonate and aryl carbonate bands for the frond feedstock are slightly lower than those of Frond 400. According to Usman et al. [35], biochar pyrolyzed at low temperatures have some functional properties similar to their feedstock. FT-IR analysis showed that chemical changes occurred in biochar during pyrolysis at various temperatures. The leaf and frond feedstocks were dehydrated upon increases in the pyrolysis temperature,

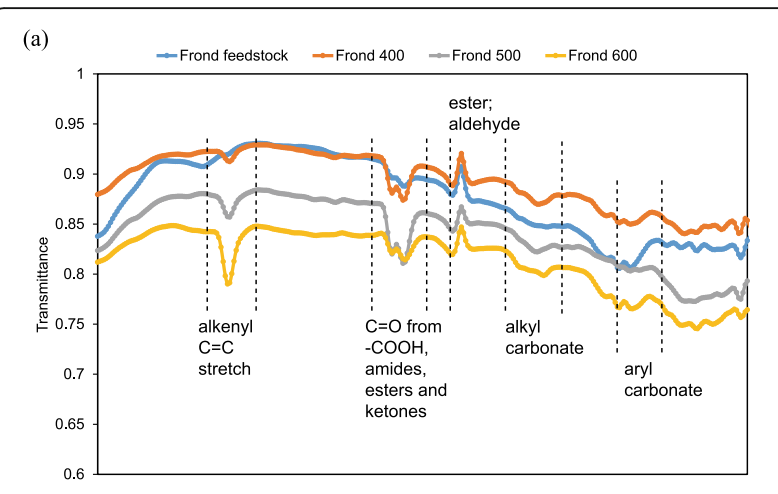

(b)

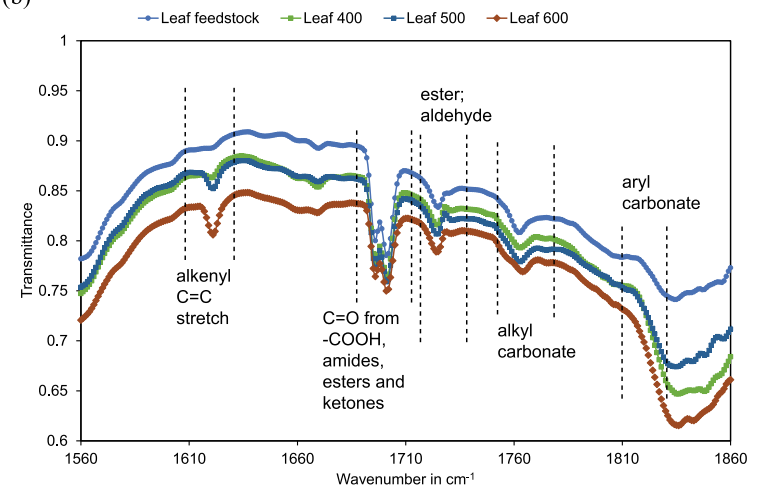

Fig. 3 FT-IR for feedstocks and biochar pyrolyzed at $400-600{ }^{\circ} \mathrm{C}$ for a frond and $\mathbf{b}$ leaf

whereby aliphatic bonds were converted to aromatic bonds which become stable graphene [12]. The content of carboxyl, hydroxyl and amino groups which are responsible for the sorption in leaf and frond biochar samples [42], was decreased with an increase in the pyrolysis temperature as compared to the feedstocks as shown in Fig. 3. Various functional groups such as oxygen containing functional groups present in the feedstocks and frond and leaf biochar samples can impact reactions on the surface, hydrophilicity, and electrical and catalytic properties of the samples [43].

The XRD analysis confirmed the organic mineral mellite, $\mathrm{Al}_{2}\left[\mathrm{C}_{6}(\mathrm{COO})_{6}\right] \cdot 16 \mathrm{H}_{2} \mathrm{O}$, at $21.2^{\circ}$ for the leaf feedstock and $22^{\circ}$ for the frond feedstock. However, mellite was lost during the pyrolysis and it could not be identified in any of the leaf and frond biochar samples. The peaks at 39 and $42^{\circ}$ in Frond 600 were identified as ZnS. In Frond 500 and 400 , the peaks at $41^{\circ}$ were identified as $\mathrm{CaCO}_{3}$ as well as the peak at $48^{\circ}$ in Leaf 500. At higher temperatures, calcium concentration decreases due to the calcination of calcium carbonate to soluble calcium oxide [22]. Hence, no $\mathrm{CaCO}_{3}$ peaks were identified in Leaf 600 and Frond $600 . \mathrm{Sr}_{2} \mathrm{FeNbO}_{6}$ was identified at peak $47^{\circ}$ in Frond $500 . \mathrm{NaBr}$ was found at peak $28^{\circ}$ in Leaf 500 and 600. Broad peaks at $30^{\circ}$ in Leaf 400 was indicative of amorphous carbon. The list of minerals identified along 
with their peak positions for leaf and frond feedstock is given in Fig. 4a and that of frond and leaf biochar in Fig. 4b. The presence of carbonate, calcite, and quartz, in the samples was probably due to the soil particles mixed with the leaf and frond feedstocks during the picking date palm waste from source or from the entrapment of carbon dioxide gas during the pyrolysis. In the Emirate of Abu Dhabi, soils are broadly classified into sandy, sandy-calcareous, gypsiferous, saline, saline-gypsiferous and hard pan soils. Calcareous or $\mathrm{CaCO}_{3}$ containing soils originate from either the weathering of the parent material or dust rich with $\mathrm{CaCO}_{3}$ brought over from the desert [44]. The source of calcium oxalate on leaf and frond biochar samples is phytolite found in leaves, wood and the bark of plants, and as the pyrolysis temperature increases, phytolite is converted into calcite [39]. $\mathrm{Sr}_{2} \mathrm{FeNbO}_{6}$ and $\mathrm{NaBr}$ originate from date palm leaf and frond. According to the previous study [45], the mineral composition of palm leaves includes a significant concentration of $\mathrm{Na}$ and Fe.

The BET surface areas of frond feedstock, Frond 400, 500 and 600 were 1.1, 3.8, 208 and $246 \mathrm{~m} 2 \mathrm{~g}-1$, respectively and the BET surface areas for leaf feedstock, Leaf 400, 500 and 600 were 1.9, 3.5, 152 and $232 \mathrm{~m} 2$ g-1, respectively as shown in Table 3 . The BET results of frond and leaf biochar samples were in parallel with the other studies as shown in Table $3[34,37,46-48]$. The BET surface area for date palm feedstock was reported to be in the range of $1-4 \mathrm{~m} 2 \mathrm{~g}-1[34,37,47]$. The date palm biochar pyrolyzed between $300-700{ }^{\circ} \mathrm{C}$ showed BET surface areas of 5.5-249 $\mathrm{m} 2 \mathrm{~g}-1$ [46]. BET analysis reveals that as pyrolysis temperature increases from 400 to 600 ${ }^{\circ} \mathrm{C}$, date palm leaf and frond biochar BET surface area increases as well. At higher pyrolysis temperature, aliphatic alkyls and ester functional groups disappeared upon exposing to the aromatic lignin core [49].

(a)

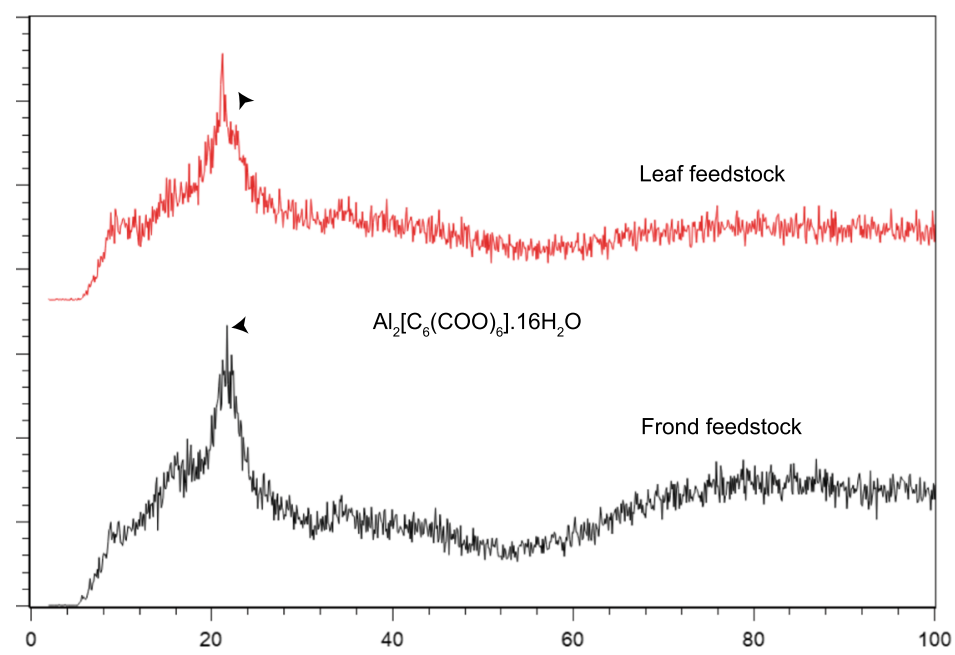

(b)

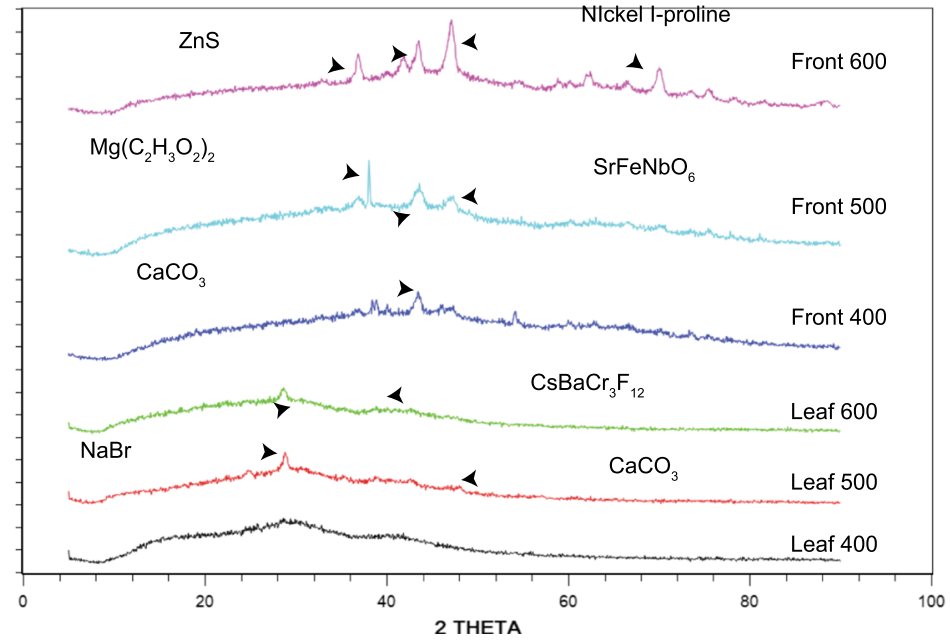

Fig. 4 XRD spectra of a leaf-frond feedstocks and $\mathbf{b}$ leaf-frond biochar samples 
Table 3 BET analysis results and comparison with biochar derived from palm material

\begin{tabular}{|c|c|c|}
\hline Biochar derived from palm material & BET surface area $\left(\mathrm{m}^{2} \mathrm{~g}^{-1}\right)$ & Reference \\
\hline Feedstock-palm frond & 1.0 & {$[34]$} \\
\hline Biochar-palm frond & 2.0 & \\
\hline Feedstock-palm frond & 4 & {$[37]$} \\
\hline Biochar-palm frond & 9 & \\
\hline Activated carbon & 322 & \\
\hline Feedstock- date palm waste & 1.0 & {$[46]$} \\
\hline Date palm biochar at $300^{\circ} \mathrm{C}$ & 2.0 & \\
\hline Date palm biochar at $400^{\circ} \mathrm{C}$ & 5.5 & \\
\hline Date palm biochar at $500^{\circ} \mathrm{C}$ & 124 & \\
\hline Date palm biochar at $600^{\circ} \mathrm{C}$ & 221 & \\
\hline Date palm biochar at $700^{\circ} \mathrm{C}$ & 249 & \\
\hline Feedstock-date palm fibers & 1.5 & [47] \\
\hline Date palm rachis biochar at $300^{\circ} \mathrm{C}$ & 15.8 & [48] \\
\hline Date palm rachis biochar at $700^{\circ} \mathrm{C}$ & 268 & \\
\hline Date palm frond feedstock & 1.1 & This study \\
\hline Biochar Frond 400 & 3.8 & This study \\
\hline Biochar Frond 500 & 152 & This study \\
\hline Biochar-Frond 600 & 246 & This study \\
\hline Biochar Leaf 400 & 3.5 & This study \\
\hline Biochar Leaf 500 & 152 & This study \\
\hline Biochar Leaf 600 & 289 & This study \\
\hline Date palm leaf feedstock & 1.9 & This study \\
\hline
\end{tabular}

The pore size distribution of leaf and frond biochar pyrolyzed at 400,500 and $600{ }^{\circ} \mathrm{C}$ is shown in Fig. 5 . It can be deduced that as the pyrolysis temperature increases, the pore volume increases and the pore diameter decreases. With increasing pyrolysis temperature, the organic matter decomposes resulting in the formation of micropores [49]. These results are in parallel with other reported studies. According to Yuan et al. [50], when the pyrolysis temperature of biochar made from sewage sludge increased from 300 to $700{ }^{\circ} \mathrm{C}$, the pore volume increased from $0.08-0.13 \mathrm{~mL} \mathrm{~g}^{-1}$. According to Zhao et al. [51], the pore diameter for biochar pyrolyzed at 500 and $650{ }^{\circ} \mathrm{C}$ was 4.0 and $2.2 \mathrm{~nm}$, respectively. As more labile material is removed, smaller diameter pores begin to form [51].

\section{Removal studies}

Date palm leaf and frond biochar samples pyrolyzed at different temperatures were tested to remove single copper, iron, zinc and nickel, and mixed metal solution at pH 2, 4, 6, 7, 8 and 10.

\section{Single metal removal/sorption capacity studies}

It was observed that as the $\mathrm{pH}$ increased, copper, zinc, nickel and iron removal efficiencies and sorption capacity (qe) in single metal solution by leaf and frond biochar samples increased as well. Copper removal efficiency and sorption capacity increased from $\mathrm{pH}$ 2-6 then the increase in the efficiency/sorption capacity was moderate at $\mathrm{pH} 7$, 8 and 10. The highest average copper removal efficiencies were all similar, or close to $99 \%$ (qe: $2.7 \mathrm{mg} \mathrm{g}^{-1}$ ) for all pyrolyzed leaf and frond biochars at three temperatures at pH 7 as shown in Fig. 6a and Table 4. Similarly, iron removal efficiencies increased from $\mathrm{pH} 2$ to 6 , and then a slight increment was observed at $\mathrm{pH} 7,8$ and 10. The highest average iron removal efficiencies were between 97 and $99 \%$ (qe: $2.7-2.9 \mathrm{mg} \mathrm{g}^{-1}$ ) all for all pyrolyzed leaf and frond biochars at three temperatures at $\mathrm{pH} 7$ and $\mathrm{pH} 6$ as shown in Fig. 6b and Table 4. In parallel to iron and copper, nickel removal efficiency increased as the $\mathrm{pH}$ was increased. The highest average removal efficiencies for nickel were $82 \%$ for Leaf 400 (qe: $2.0 \mathrm{mg} \mathrm{g}^{-1}$ ), $98 \%$ for Leaf 500 (qe: $2.4 \mathrm{mg} \mathrm{g}^{-1}$ ), $99 \%$ for Leaf 600 (qe: $2.4 \mathrm{mg} \mathrm{g}^{-1}$ ), 96\% for Frond 400 (qe: $2.4 \mathrm{mg} \mathrm{g}^{-1}$ ), $53 \%$ for Frond 500 (qe: $1.3 \mathrm{mg} \mathrm{g}^{-1}$ ) and $96 \%$ for Frond 600 (qe: $2.4 \mathrm{mg} \mathrm{g}^{-1}$ ) at pH 10 as shown in Fig. $6 \mathrm{c}$ and Table 4. For zinc, the removal efficiencies increased as the $\mathrm{pH}$ was increased to $\mathrm{pH} 7,8$ and 10. The highest average removal efficiencies were $97 \%\left(2.7 \mathrm{mg} \mathrm{g}^{-1}\right)$ at $\mathrm{pH} \mathrm{10,90 \%} \mathrm{for} \mathrm{Frond} 400$ (qe: $2.7 \mathrm{mg} \mathrm{g}^{-1}$ ) and $98 \%$ for Frond 600 (qe: $3.0 \mathrm{mg} \mathrm{g}^{-1}$ ) at $\mathrm{pH}$ 7 as shown in Fig. $6 \mathrm{~d}$ and Table 4. 
(a)

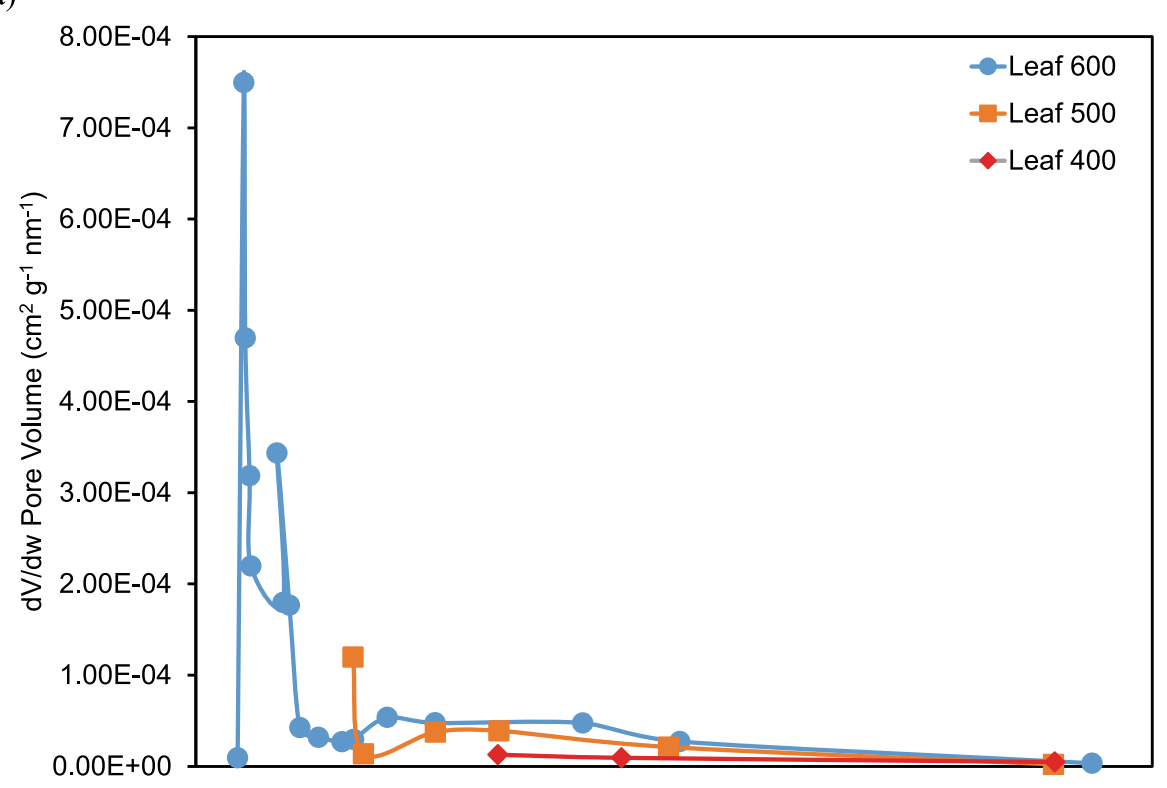

(b)

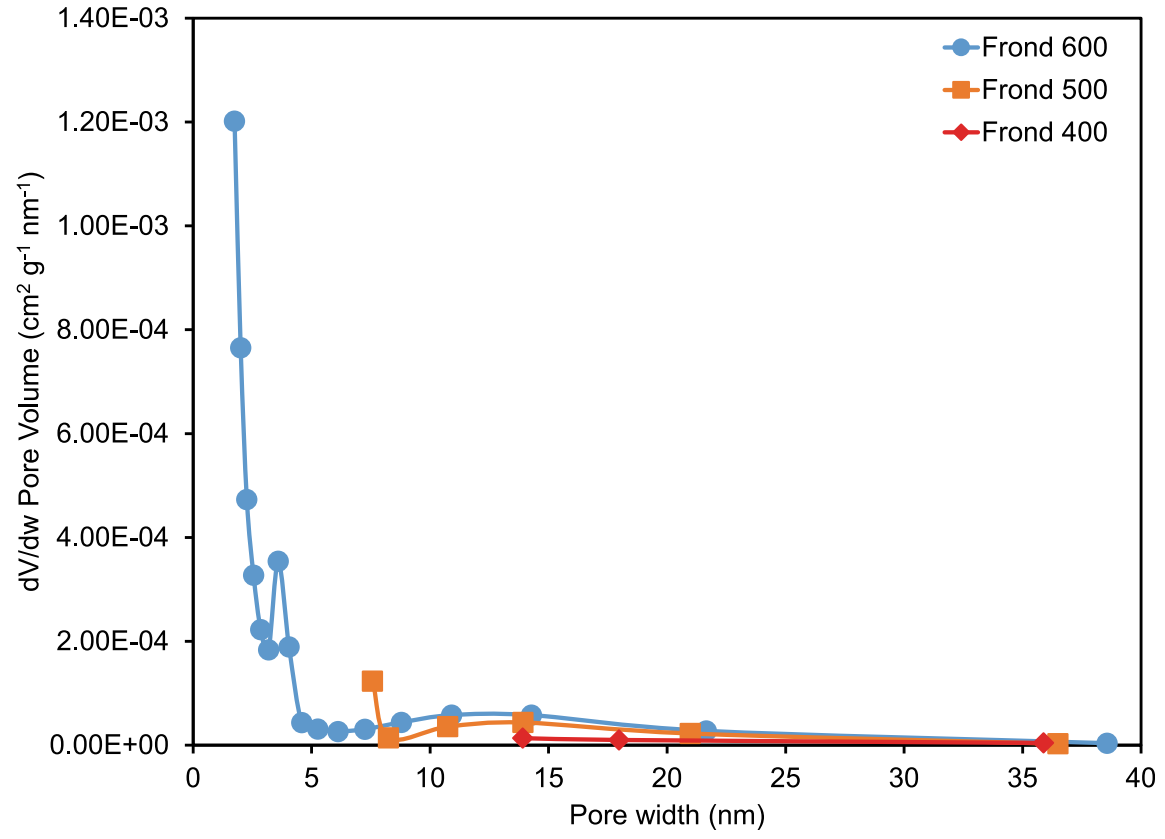

Fig. 5 Pore size distribution at various pyrolysis temperatures of a leaf biochar $\mathbf{b}$ frond biochar

\section{Mixed metal solutions}

In a similar fashion, it was observed that when $\mathrm{pH}$ was increased, copper, zinc, nickel and iron removal efficiencies in mixed-metal solutions increased by leaf and frond biochar samples. Copper removal efficiencies were comparably lower between $\mathrm{pH} 2$ and 4. However, a slight increase was observed beyond $\mathrm{pH} 6$. The highest average removal efficiencies were close to $100 \%$ for all leaf and frond biochars (qe: $2.51-2.7 \mathrm{mg} \mathrm{g}^{-1}$ ) at $\mathrm{pH} 7,8$ and 10 as shown in Fig. 6e and Table 4. Iron removal efficiencies increased from $\mathrm{pH} 2$ to 6 , and slight increments were observed beyond $\mathrm{pH} 6$. The highest average removal efficiencies were $94-95 \%$ for all pyrolyzed leaf and frond biochars at $\mathrm{pH} 6$ and 7 as shown in Fig. $6 \mathrm{f}$ and Table 4. Nickel removal efficiencies were low at low $\mathrm{pH}$ values $(\mathrm{pH} 2-4)$ similar to copper, and removal efficiencies increased when $\mathrm{pH}$ was raised beyond 6 . The highest average removal efficiencies were close to $100 \%$ 
(a)

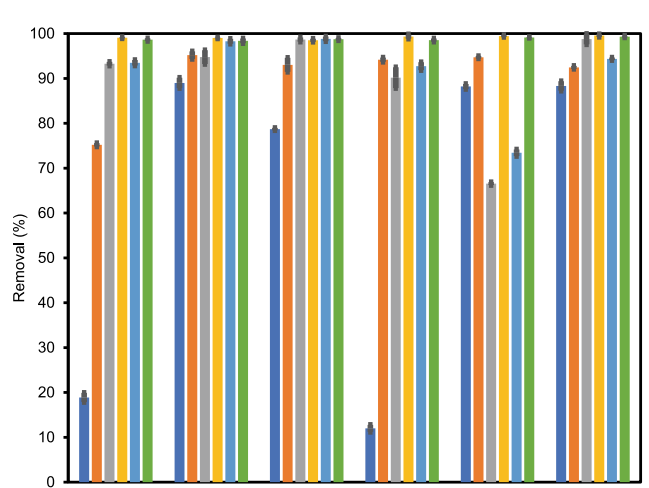

(c)

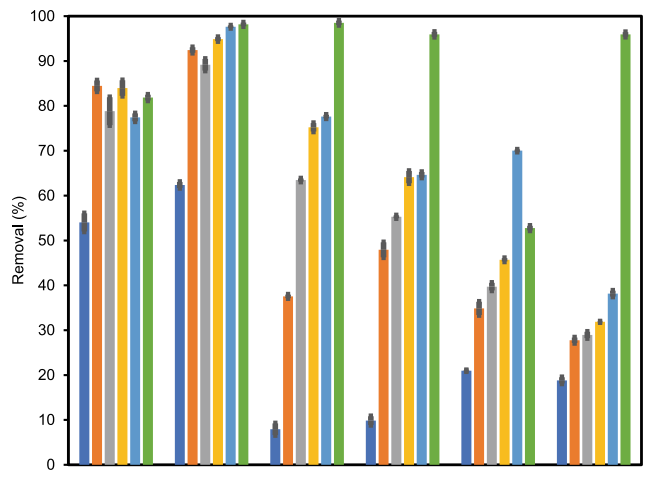

(e)

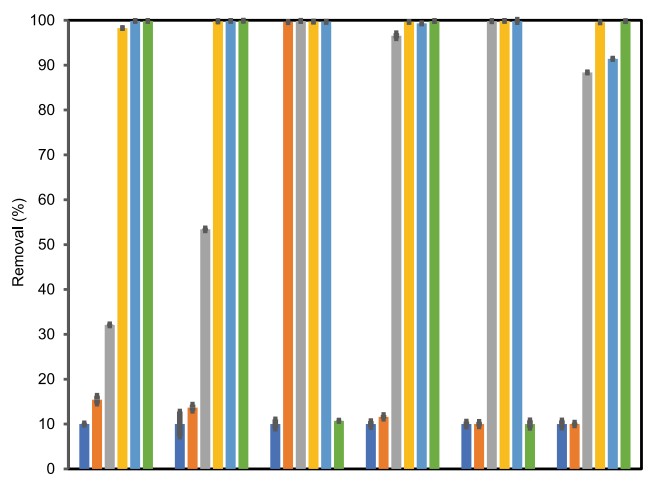

(g)

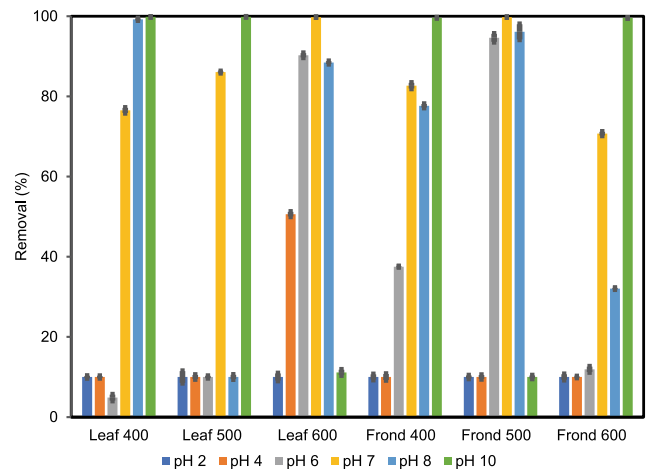

(b)

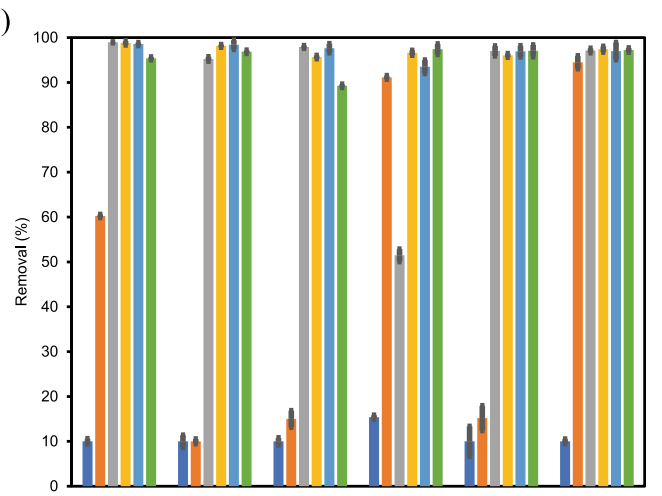

(d)

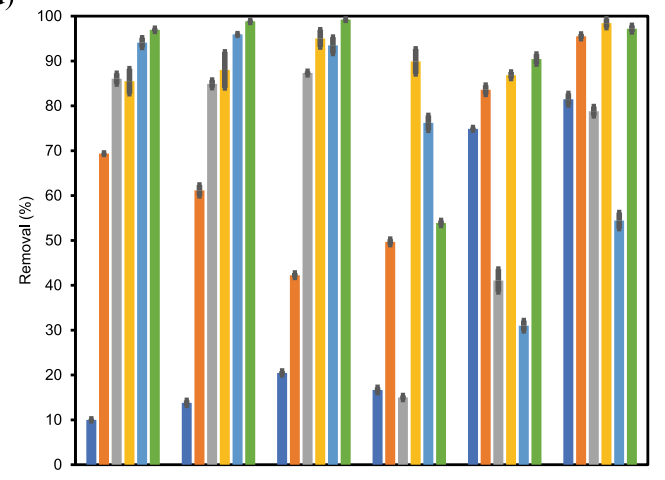

(f)

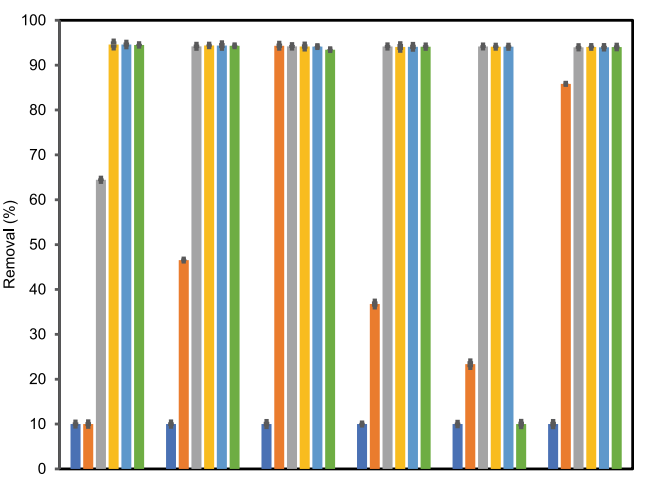

(h)

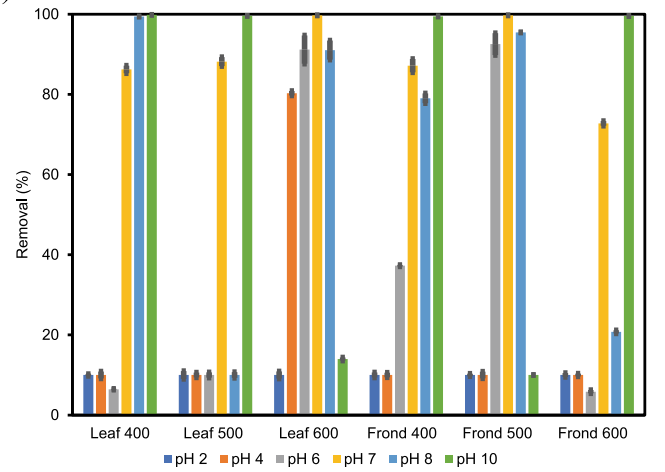

Fig. $\mathbf{6}$ The removal efficiencies of a copper, $\mathbf{b}$ iron, $\mathbf{c}$ nickel, $\mathbf{d}$ zinc, in single metal solutions and $\mathbf{e}$ copper $\mathbf{f}$ iron, $\mathbf{g}$ nickel and $\mathbf{h}$ zinc in mixed metal solution by biochar samples 


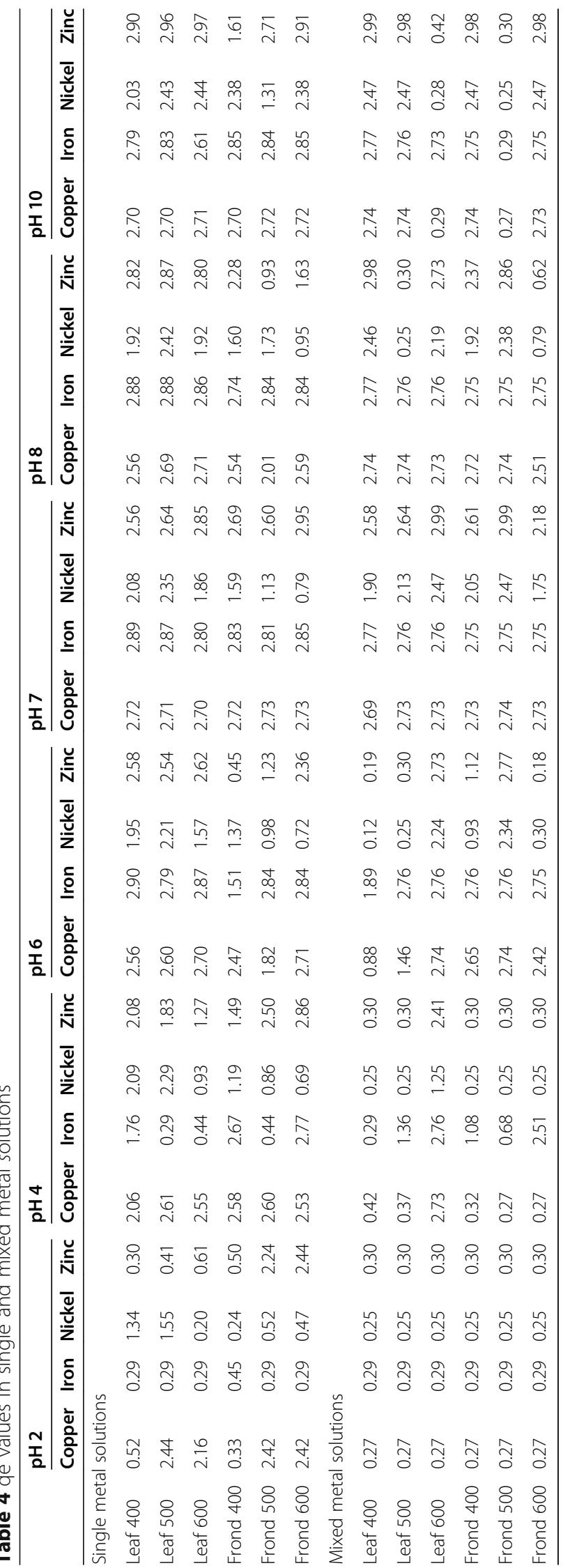


(qe: $2.47 \mathrm{mg} \mathrm{g}^{-1}$ ) for all pyrolyzed leaf and frond biochars at $\mathrm{pH} 7$ as shown in Fig. 6g. Zinc removal increased when $\mathrm{pH}$ was increased beyond $\mathrm{pH} 6$, and the highest average removal efficiencies were close to $100 \%$ (qe: $3.0 \mathrm{mg} \mathrm{g}^{-1}$ ) for all pyrolyzed leaf and frond biochars at $\mathrm{pH} 7,8$ and 10 as shown in Fig. $6 \mathrm{~h}$ and Table 4.

As a result, at the $\mathrm{pH}$ values beyond 6 , the removal efficiencies and qe of metal ions in single and mixed metals solutions were higher, and this observation is in parallel with the other reported studies. Chen et al. [17] reported that when using hardwood and corn stalks biochar, the removal efficiencies of copper and zinc increased when the $\mathrm{pH}$ increased from 2 to 5. Similarly, it was found that copper removal was higher at $\mathrm{pH} 6.0$ as compared to $\mathrm{pH} 3.5$ using three different biochar [52]. Kilic et al. [53] investigated the effect of $\mathrm{pH}$ on the adsorption of nickel and cobalt onto almond shell biochar, and it was found that the adsorption capacity increased from 0 to $10 \mathrm{mg} \mathrm{g}^{-1}$ for nickel and from 10 to 30 $\mathrm{mg} \mathrm{g}^{-1}$ for cobalt as the $\mathrm{pH}$ was increased from 2 to 6 . When the $\mathrm{pH}$ is further increased beyond 6 , the adsorption capacity reduced to nearly $0 \mathrm{mgg}^{-1}$ for nickel and $10 \mathrm{mg} \mathrm{g}^{-1}$ for cobalt. The effect of the $\mathrm{pH}$ on the adsorption of copper onto biochar derived from compost, rice husks, orange waste and olive pomace was studied over the $\mathrm{pH}$ range of 2 to 7 . Removal efficiencies increased at higher $\mathrm{pH}$ values, and the optimum value was found to be $\mathrm{pH} 7$ for all samples with removal efficiencies of $94 \%$ with compost, $90 \%$ with rice husks, $89 \%$ with orange waste, and $78 \%$ with olive pomace [19].

The $\mathrm{pH}$ of aqueous solutions influences the adsorbent's surface charge and ionization as well as the ionization and speciation of the adsorbate [18]. Low removal efficiencies at lower $\mathrm{pH}$ values can be attributed to excess $\mathrm{H}^{+}$ion concentration resulting in competition between $\mathrm{H}^{+}$and metals for available sites on the biochar. Furthermore, at lower $\mathrm{pH}$ values protonation of the acidic functional groups on biochar occurs leaving a positively charged surface which can repel the metal ions, thereby decreasing the removal efficiencies [35, 43]. At higher $\mathrm{pH}$ values, deprotonation of hydroxyl and carboxylic groups on the biochar creates negatively charged surfaces leading to removal of the metal cations through electrostatic attraction. Generally, there are more available binding sites for metal cations at higher $\mathrm{pH}$ values because of lower $\mathrm{H}^{+}$ion concentration causing less competition for the binding sites, hence increasing the removal efficiencies. Kolodynska et al. [54] and Usman et al. [55] have also reported that heavy metal ion adsorption on biochar increased as the $\mathrm{pH}$ was increased. When the $\mathrm{pH}$ of the solution increases, metals ions become less soluble and start to precipitate as metal hydroxide. As the $\mathrm{pH}$ of solution increases, zinc presents as $\mathrm{Zn}^{2+}$ at $\mathrm{pH}<8.8$ and presents as zinc hydroxides at $\mathrm{pH}>8.8$ [56]. Copper presents as $\mathrm{Cu}^{2+}$ at $\mathrm{pH}<5.8$ and presents as copper hydroxide at $\mathrm{pH}>5.8$ [57]. Nickel presents as nickel hydroxide at basic solutions [58]. $\mathrm{Fe}$ (II) ions form iron hydroxide at alkaline ranges $[58,59]$. It has to be noted that at higher $\mathrm{pH}$ values, both the adsorption of metal ions through electrostatic attraction and the precipitation process contribute to the removal efficiencies.

\section{The statistical analysis on feedstock and pyrolysis effect on removal}

The removal efficiencies for single and mixed metal ion solutions were between $98 \%$ and close to $100 \%$ for all metals by leaf and frond biochar samples at $\mathrm{pH}>6$. The two-tailed t-test and one-way ANOVA tests were found to be not statistically significant (at the 0.05 level) among date palm frond and leaf biochar samples at different pyrolysis temperatures at the same $\mathrm{pH}$ values shown in Table 5 . The only exception was nickel removal efficiencies in single metal solutions between Leaf 400 and 500 and between Frond 400, 500 and 600. According to these results, it can be inferred that the increase of the pyrolysis temperature does not make any significance in terms of copper, iron, nickel and zinc percent removal in both single and mixed metal solutions. Although higher pyrolysis temperatures increased the surface area of the biochar, this feature is not the sole factor affecting the removal capacity of adsorbent. Other surface characteristics such as cation exchange, surface precipitation of carbonate, and surface complexation with oxygen-containing groups also affect the removal efficiency [13].

The significance to use date palm frond or leaf as biochar feedstock to remove single metal ion or mixed metal ions was analyzed using two-tailed $t$ test as shown in Table 6. According to the $t$ test results, only using Leaf 500 to Frond 500 to remove the nickel was statistically significant in single ion solutions. As a conclusion, using different date palm feedstocks at different temperatures did not make any significance to remove single or mixed metals from aqueous solutions.

Using different feedstock of date palm or different pyrolysis temperatures did not make any statistical significance to remove single or mixed metal ions, and this observation is in alignment with the other reported studies as well. According to Lou et al. [60], the pyrolysis temperature did not affect the phosphate adsorption on the biochar. In the same manner, biochar samples 
Table 5 T test and one-way ANOVA $p$ values comparing different pyrolysis temperatures for biochar samples

\begin{tabular}{|c|c|c|c|c|c|c|c|c|c|}
\hline \multirow[t]{2}{*}{ Ion } & & \multicolumn{6}{|l|}{ T test } & \multicolumn{2}{|c|}{ One-way ANOVA } \\
\hline & & $\begin{array}{l}\text { Leaf } 400 \\
\text { and } 500\end{array}$ & $\begin{array}{l}\text { Leaf } 500 \\
\text { and } 600\end{array}$ & $\begin{array}{l}\text { Leaf } 400 \\
\text { and } 600\end{array}$ & $\begin{array}{l}\text { Frond } 400 \\
\text { and } 500\end{array}$ & $\begin{array}{l}\text { Frond } 500 \\
\text { and } 600\end{array}$ & $\begin{array}{l}\text { Frond } 400 \\
\text { and } 600\end{array}$ & $\begin{array}{l}\text { Leaf } 400,500 \\
\text { and } 600\end{array}$ & $\begin{array}{l}\text { Frond } 400,500 \\
\text { and } 600\end{array}$ \\
\hline \multirow{4}{*}{$\begin{array}{l}\text { Single } \\
\text { metal ion }\end{array}$} & Copper & 0.4 & 0.31 & 0.16 & 0.27 & 0.17 & 0.31 & 0.94 & 0.16 \\
\hline & Iron & 0.52 & 0.38 & 0.25 & 0.32 & 0.16 & 0.31 & 0.89 & 0.98 \\
\hline & Nickel & 0.0019 & 0.07 & 0.74 & 0.22 & 0.97 & 0.44 & 0.13 & 0.001 \\
\hline & Zinc & 0.68 & 0.67 & 0.38 & 0.86 & 0.59 & 0.60 & 0.22 & 0.73 \\
\hline \multirow{4}{*}{$\begin{array}{l}\text { Mixed } \\
\text { metal ions }\end{array}$} & Copper & 0.79 & 0.68 & 0.37 & 0.38 & 0.47 & 0.22 & 0.91 & 0.84 \\
\hline & Iron & 0.37 & 0.11 & 0.52 & 0.35 & 0.35 & 0.034 & 0.69 & 0.55 \\
\hline & Nickel & 0.41 & 0.97 & 0.42 & 0.58 & 0.97 & 0.40 & 0.85 & 0.79 \\
\hline & Zinc & 0.36 & 0.95 & 0.38 & 0.53 & 0.91 & 0.36 & 0.53 & 0.73 \\
\hline
\end{tabular}

derived from orange peel pyrolyzed at 400, 500, 600, 700 and $800^{\circ} \mathrm{C}$ did not make any statistically significant difference in the adsorption of cadmium [61]. Biochar derived from giant Miscanthus pyrolyzed at the ranges $300-600{ }^{\circ} \mathrm{C}$ did not increase the adsorption of cadmium to a significant extent [62]. Similarly, biochar derived from mulberry pyrolyzed at 350,450 , and $550{ }^{\circ} \mathrm{C}$ produced similar adsorption capacities for $\mathrm{Pb}$ (II) [12]. Therefore, it was concluded that changing pyrolysis temperature or changing feedstock for palm-derived biochar will not make any significant improvement to remove metals; therefore, the energy requirement to produce palm-derived biochar at lower temperature will be less for mass production. In fact, biochar can be pyrolyzed at site with available energy sources, and it can be utilized effectively to remove contaminants.

\section{Conclusions}

Our study investigated the effect of $\mathrm{pH}$, feedstock type, and pyrolysis temperature at 400,500 and $600{ }^{\circ} \mathrm{C}$ on the capacity of date palm waste derived biochar to remove copper, iron, nickel and zinc in single and mixed metal solutions. It was found that biochar pyrolyzed at higher temperatures did not produce statistically significant removal efficiencies for the heavy metal ions when compared to biochar pyrolyzed at lower temperatures. In economical perspective, it was concluded that the energy consumption to produce palm-derived biochar at lower temperature will be less and cost effective.

However, pyrolysis temperature was found to influence both surface chemistry and physical characteristics. Biochar pyrolyzed at high temperatures lost most of their functional properties as compared to the feedstock. From FT-IR spectra, it was observed that $-\mathrm{OH}$ stretching and other volatile groups decreased in biochar samples. As for the surface structure, surface area and pore volume increased with increased pyrolysis temperature and they became more porous, and showed deep channels due to the volatilization of organic matter. With increasing pyrolysis temperature, hydrogen, oxygen, nitrogen and sulfur content decreased while carbon content increased due to carbonization. Feedstock type was shown not be a statistically significant criterion for the metal removal. The removal efficiencies for single metal and mixed metal ions were between $98 \%$ and close to $100 \%$ for nickel, iron, zinc and copper by leaf and frond biochar samples at $\mathrm{pH}>6$. However, lower removal efficiencies less than $50 \%$ was observed at $\mathrm{pH} 2-4$ range generally for the leaf and frond biochar. The leaf or frond date palm biochar are effective low-cost absorbents for removing metals. Utilizing date palm waste materials to produce biochar is a sustainable solution due to its negative impact on GWP, cost effectiveness and waste management perspective.

Table 6 T test $p$ values to compare different feedstocks as biochar material

\begin{tabular}{|c|c|c|c|c|c|c|}
\hline \multirow[b]{2}{*}{ Ion } & \multicolumn{3}{|c|}{ Single metal ions removal } & \multicolumn{3}{|c|}{ Mixed metal ions removal } \\
\hline & $\begin{array}{l}\text { Leaf } 400 \text { and Frond } \\
400\end{array}$ & $\begin{array}{l}\text { Leaf } 500 \text { and Frond } \\
500\end{array}$ & $\begin{array}{l}\text { Leaf } 600 \text { and Frond } \\
600\end{array}$ & $\begin{array}{l}\text { Leaf } 400 \text { and Frond } \\
400\end{array}$ & $\begin{array}{l}\text { Leaf } 500 \text { and Frond } \\
500\end{array}$ & $\begin{array}{l}\text { Leaf } 600 \text { and Frond } \\
600\end{array}$ \\
\hline Copper & 0.74 & 0.18 & 0.59 & 0.36 & 0.68 & 0.47 \\
\hline Iron & 0.28 & 0.63 & 0.35 & 0.38 & 0.35 & 0.85 \\
\hline Nickel & 0.29 & 0.0008 & 0.14 & 0.87 & 0.49 & 0.53 \\
\hline Zinc & 0.16 & 0.27 & 0.43 & 0.91 & 0.51 & 0.44 \\
\hline
\end{tabular}




\section{Acknowledgments}

The authors wish to thank Dr. Agathe Talarmin for conducting CHNS Analysis and Dr. Grzegorz Brudecki for helping ICP-MS analysis.

\section{Authors' contributions}

Banu Sizirici contributed: Conceptualization, Methodology, Investigation, Writing - Review \& Editing, Yohanna Fseha contributed: Investigation, Writing, Ibrahim Yildiz contributed: Validation, Writing - Review \& Editing, Thomas Delclos contributed: Resources, Abbas Khaleel contributed: Resources. The author(s) read and approved the final manuscript.

\section{Funding}

This research was supported by Khalifa University and Dubai Electric and Water Authority, UAE through the Mohammed bin Rashid Al Maktoum Global Water Award 2019 Innovative Research and Development, National Institutions program (Grant number: 8434000361).

\section{Availability of data and materials}

All data generated or analyzed during this study are available upon request.

\section{Competing interests}

The authors declare they have no competing interests.

\section{Author details}

${ }^{1}$ Civil Infrastructure and Environmental Engineering Department, Khalifa University Science and Technology, Abu Dhabi, United Arab Emirates. ${ }^{2}$ Chemistry Department, Khalifa University Science and Technology, Abu Dhabi, United Arab Emirates. ${ }^{3}$ Research Laboratories, Khalifa University of Science and Technology, Abu Dhabi, United Arab Emirates. ${ }^{4}$ Chemistry Department, United Arab Emirates University, Al Ain, United Arab Emirates.

\section{Received: 11 August 2020 Accepted: 9 February 2021}

\section{Published online: 25 February 2021}

\section{References}

1. Ahmad M, Rajapaksha AU, Lim JE, Zhang M, Bolan N, Mohan D, et al. Biochar as a sorbent for contaminant management in soil and water: a review. Chemosphere. 2014;99:19-33.

2. Sizirici B, Yildiz I. Simultaneous adsorption of divalent and trivalent metal cations by iron oxide-coated gravel. Int J Environ Sci Te. 2018;15:2647-56.

3. Nayak A, Bhushan B, Gupta V, Sharma P. Chemically activated carbon from lignocellulosic wastes for heavy metal wastewater remediation: effect of activation conditions. J Colloid Interf Sci. 2017:493:228-40.

4. Amin MT, Alazba AA, Shafiq M. Adsorption of copper $\left(\mathrm{Cu}^{2+}\right)$ from aqueous solution using date palm trunk fibre: isotherms and kinetics. Desalin Water Treat. 2016;57:22454-66.

5. Sulyman M, Namiesnik J, Gierak A. Low-cost adsorbents derived from agricultural by-products/wastes for enhancing contaminant uptakes from wastewater: a review. Pol J Environ Stud. 2017;26:479-510.

6. Shen YS, Wang SL, Tzou YM, Yan YY, Kuan WH. Removal of hexavalent Cr by coconut coir and derived chars - the effect of surface functionality. Bioresour Technol. 2012;104:165-72.

7. Lehmann J, Joseph S. Biochar for environmental management: science, technology and implementation. 2nd ed. Oxon, Routledge; 2015.

8. Graber ER, Harel YM, Kolton M, Cytryn E, Silber A, David DR, et al. Biochar impact on development and productivity of pepper and tomato grown in fertigated soilless media. Plant Soil. 2010;337:481-96.

9. Tan XF, Liu YG, Zeng GM, Wang X, Hu XJ, Gu YL, et al. Application of biochar for the removal of pollutants from aqueous solutions. Chemosphere. 2015;125:70-85.

10. Wang ZY, Cao JQ, Wang J. Pyrolytic characteristics of pine wood in a slowly heating and gas sweeping fixed-bed reactor. J Anal Appl Pyrol. 2009;84: 179-84.

11. Al-Wabel Ml, Al-Omran A, El-Naggar AH, Nadeem M, Usman ARA. Pyrolysis temperature induced changes in characteristics and chemical composition of biochar produced from conocarpus wastes. Bioresour Technol. 2013;131: 374-9.

12. Zama EF, Zhu YG, Reid BJ, Sun GX. The role of biochar properties in influencing the sorption and desorption of $\mathrm{Pb}(\mathrm{III}) \mathrm{Cd}$ (II) and $\mathrm{As}$ (III) in aqueous solution. J Clean Prod. 2017;148:127-36.
13. Sun JK, Lian F, Liu ZQ, Zhu LY, Song ZG. Biochars derived from various crop straws: characterization and Cd (II) removal potential. Ecotox Environ Safe. 2014;106:226-31.

14. Chen T, Zhang YX, Wang HT, Lu WJ, Zhou ZY, Zhang YC, et al. Influence of pyrolysis temperature on characteristics and heavy metal adsorptive performance of biochar derived from municipal sewage sludge. Bioresour Technol. 2014;164:47-54

15. Zbair M, Anfar Z, Ahsaine HA, Khallok H. Kinetics, equilibrium, statistical surface modeling and cost analysis of paraquat removal from aqueous solution using carbonated jujube seed. RSC Adv. 2019;9:1084-94.

16. Li B, Yang L, Wang CQ, Zhang QP, Liu QC, Li YD, et al. Adsorption of Cd (II) from aqueous solutions by rape straw biochar derived from different modification processes. Chemosphere. 2017:175:332-40.

17. Chen $X C$, Chen $G C$, Chen $L G$, Chen $Y X$, Lehmann J, McBride MB, et al. Adsorption of copper and zinc by biochars produced from pyrolysis of hardwood and corn straw in aqueous solution. Bioresour Technol. 2011;102: 8877-84.

18. Regmi P, Moscoso JLG, Kumar S, Cao XY, Mao JD, Schafran G. Removal of copper and cadmium from aqueous solution using switchgrass biochar produced via hydrothermal carbonization process. J Environ Manage. 2012; 109:61-9.

19. Pellera FM, Giannis A, Kalderis D, Anastasiadou K, Stegmann R, Wang $J Y$, et al. Adsorption of $\mathrm{Cu}$ (II) ions from aqueous solutions on biochars prepared from agricultural by-products. J Environ Manage. 2012:96:35-42.

20. Agrafioti E, Kalderis D, Diamadopoulos E. Ca and Fe modified biochars as adsorbents of arsenic and chromium in aqueous solutions. J Environ Manage. 2014;146:444-50

21. Kong HL, He J, Gao YZ, Wu HF, Zhu XZ. Cosorption of phenanthrene and mercury (II) from aqueous solution by soybean stalk-based biochar. J Agr Food Chem. 2011;59:12116-23.

22. Mohan D, Pittman CU, Bricka M, Smith F, Yancey B, Mohammad J, et al. Sorption of arsenic, cadmium, and lead by chars produced from fast pyrolysis of wood and bark during bio-oil production. J Colloid Interf Sci. 2007;310:57-73

23. Dong $X L, M a L N Q$, Li YC. Characteristics and mechanisms of hexavalent chromium removal by biochar from sugar beet tailing. J Hazard Mater. 2011;190:909-15.

24. Liu ZG, Zhang FS. Removal of lead from water using biochars prepared from hydrothermal liquefaction of biomass. J Hazard Mater. 2009;167:933-9.

25. Zhou YM, Gao B, Zimmerman AR, Fang J, Sun YN, Cao XD. Sorption of heavy metals on chitosan-modified biochars and its biological effects. Chem Eng J. 2013;231:512-8.

26. Abdelhadi SO, Dosoretz CG, Rytwo G, Gerchman Y, Azaizeh H. Production of biochar from olive mill solid waste for heavy metal removal. Bioresour Technol. 2017;244:759-67.

27. Cobbina SJ, Duwiejuah AB, Quainoo AK. Single and simultaneous adsorption of heavy metals onto groundnut shell biochar produced under fast and slow pyrolysis. Int J Environ Sci Te. 2019;16:3081-90.

28. Cheng QM, Huang Q, Khan S, Liu YJ, Liao ZN, Li G, et al. Adsorption of Cd by peanut husks and peanut husk biochar from aqueous solutions. Ecol Eng. 2016;87:240-5.

29. Chi T, Zuo J, Liu FL. Performance and mechanism for cadmium and lead adsorption from water and soil by corn straw biochar. Front Env Sci Eng. 2017;11:15.

30. Cao XD, Harris W. Properties of dairy-manure-derived biochar pertinent to its potential use in remediation. Bioresour Technol. 2010;101:5222-8.

31. Zbair M, Ahsaine HA, Anfar Z, Slassi A. Carbon microspheres derived from walnut shell: rapid and remarkable uptake of heavy metal ions, molecular computational study and surface modeling. Chemosphere. 2019;231:140-50.

32. Alhashimi HA, Aktas CB. Life cycle environmental and economic performance of biochar compared with activated carbon: a meta-analysis. Resour Conserv Recy. 2017;118:13-26.

33. Roberts KG, Gloy BA, Joseph S, Scott NR, Lehmann J. Life cycle assessment of biochar systems: estimating the energetic, economic, and climate change potential. Environ Sci Technol. 2010;44:827-33.

34. Jouiad M, Al-Nofeli N, Khalifa N, Benyettou F, Yousef LF. Characteristics of slow pyrolysis biochars produced from rhodes grass and fronds of edible date palm. J Anal Appl Pyrol. 2015;111:183-90.

35. Usman ARA, Abduljabbar A, Vithanage M, Ok YS, Ahmad M, Ahmad M, et al. Biochar production from date palm waste: charring temperature induced 
changes in composition and surface chemistry. J Anal Appl Pyrol. 2015;115: 392-400.

36. Mingorance MD, Rossini Oliva S. Heavy metals content in N-oleander leaves as urban pollution assessment. Environ Monit Assess. 2006;119:57-68.

37. Som AM, Wang Z, Al-Tabbaa A. Palm frond biochar production and characterisation. Earth Env Sci T R So. 2012;103:39-48.

38. Al-Swaidan HM, Ahmad A. Synthesis and characterization of activated carbon from Saudi Arabian dates tree's fronds wastes. In: 3rd International conference on chemical, biological and environmental engineering. Singapore: IACSIT Press; 2011.

39. Singh B, Camps-Arbestain M, Lehmann J, editors. Biochar: a guide to analytical methods. Clayton: CSIRO Publishing; 2017.

40. Pariyar P, Kumari K, Jain MK, Jadhao PS. Evaluation of change in biochar properties derived from different feedstock and pyrolysis temperature for environmental and agricultural application. Sci Total Environ. 2020;713:136433.

41. Coates J. Interpretation of infrared spectra, a practical approach. In: Meyers RA, McKelvy ML, editors. Encyclopedia of analytical chemistry: applications, theory instrumentation. Chichester: John Wiley \& Sons Ltd; 2006. 10815-37.

42. Li HB, Dong XL, da Silva EB, de Oliveira LM, Chen YS, Ma LNQ. Mechanisms of metal sorption by biochars: biochar characteristics and modifications. Chemosphere. 2017;178:466-78.

43. Yang $X D$, Wan $Y S$, Zheng $Y L$, He F, Yu ZB, Huang J, et al. Surface functional groups of carbon-based adsorbents and their roles in the removal of heavy metals from aqueous solutions: a critical review. Chem Eng J. 2019;366:608-21.

44. Shahid SA, Abdelfattah MA. Soils of Abu Dhabi Emirate. In: Perry RJ, editor. Terrestrial Environment of Abu Dhabi Emirate. Abu Dhabi: Environment Agency-Abu Dhabi; 2008. p. 72-92.

45. Al Adili A, Al-Soudany K. Effect of random inclusion of date palm leaf fibers on some soil properties. Int J Earth Sci Eng. 2015;11:28-34.

46. Elnour AY, Alghyamah AA, Shaikh HM, Poulose AM, Al-Zahrani SM, Anis A, et al. Effect of pyrolysis temperature on biochar microstructural evolution, physicochemical characteristics, and its influence on biochar/polypropylene composites. Appl Sci-Basel. 2019;9:1149.

47. Riahi K, Chaabane S, Ben Thayer B. A kinetic modeling study of phosphate adsorption onto Phoenix dactylifera L. date palm fibers in batch mode. J Saudi Chem Soc. 2017;21:S143-52.

48. Alsewaileh AS, Usman AR, Al-Wabel MI. Effects of pyrolysis temperature on nitrate-nitrogen $\left(\mathrm{NO}_{3}{ }^{-}-\mathrm{N}\right)$ and bromate $\left(\mathrm{BrO}_{3}{ }^{-}\right)$adsorption onto date palm biochar. J Environ Manage. 2019;237:289-96

49. Tomczyk A, Sokolowska Z, Boguta P. Biochar physicochemical properties: pyrolysis temperature and feedstock kind effects. Rev Environ Sci Bio. 2020; 19:191-215.

50. Yuan HR, Lu T, Huang HY, Zhao DD, Kobayashi N, Chen Y. Influence of pyrolysis temperature on physical and chemical properties of biochar made from sewage sludge. J Anal Appl Pyrol. 2015;112:284-9.

51. Zhao B, O'Connor D, Zhang JL, Peng TY, Shen ZT, Tsang DCW, et al. Effect of pyrolysis temperature, heating rate, and residence time on rapeseed stem derived biochar. J Clean Prod. 2018;174:977-87.

52. Tong XJ, Li JY, Yuan JH, Xu RK. Adsorption of Cu (II) by biochars generated from three crop straws. Chem Eng J. 2011;172:828-34.

53. Kilic M, Kirbiyik C, Cepeliogullar O, Putun AE. Adsorption of heavy metal ions from aqueous solutions by bio-char, a by-product of pyrolysis. Appl Surf Sci. 2013;283:856-62.

54. Kolodynska D, Wnetrzak R, Leahy JJ, Hayes MHB, Kwapinski W, Hubicki Z. Kinetic and adsorptive characterization of biochar in metal ions removal. Chem Eng J. 2012;197:295-305.

55. Usman ARA, Sallam AS, Al-Omran A, El-Naggar AH, Alenazi KKH, Nadeem M, et al. Chemically modified biochar produced from conocarpus wastes: an efficient sorbent for Fe (II) removal from acidic aqueous solutions. Adsorpt Sci Technol. 2013;31:625-40.

56. Sizirici B, Yildiz I. Simultaneous removal of organics and metals in fixed bed using gravel and iron oxide coated gravel. Results Eng. 2020;5: 100093.

57. Albrecht TWJ, Addai-Mensah J, Fornasiero D. Effect of pH, concentration and temperature on copper and zinc hydroxide formation/precipitation in solution. In: CHEMECA: Engineering a Better World. Sydney: Engineers Australia; 2011.

58. Eckenfelder WW. Industrial water pollution control. 2nd ed. New York: McGraw Hill; 1989.
59. Sizirici B, Yildiz I, AlYammahi A, Obaidalla F, AlMehairbi M, AlKhajeh S, et al. Adsorptive removal capacity of gravel for metal cations in the absence/ presence of competitive adsorption. Environ Sci Pollut R. 2018;25:7530-40.

60. Lou KY, Rajapaksha AU, Ok YS, Chang SX. Pyrolysis temperature and steam activation effects on sorption of phosphate on pine sawdust biochars in aqueous solutions. Chem Spec Bioavailab. 2016;28:42-50.

61. Tran HN, You SJ, Chao HP. Effect of pyrolysis temperatures and times on the adsorption of cadmium onto orange peel derived biochar. Waste Manage Res. 2016;34:129-38.

62. Kim WK, Shim T, Kim YS, Hyun S, Ryu C, Park YK, et al. Characterization of cadmium removal from aqueous solution by biochar produced from a giant Miscanthus at different pyrolytic temperatures. Bioresour Technol. 2013;138:266-70.

\section{Publisher's Note}

Springer Nature remains neutral with regard to jurisdictional claims in published maps and institutional affiliations.

\section{Ready to submit your research? Choose BMC and benefit from:}

- fast, convenient online submission

- thorough peer review by experienced researchers in your field

- rapid publication on acceptance

- support for research data, including large and complex data types

- gold Open Access which fosters wider collaboration and increased citations

- maximum visibility for your research: over $100 \mathrm{M}$ website views per year

At BMC, research is always in progress.

Learn more biomedcentral.com/submissions 